\title{
Pendidikan Kebahagiaan dalam Revolusi Industri 4
}

\author{
Wahyudi Setiawan \\ Universitas Muhammadiyah Ponorogo \\ wahyudisetiawan@umpo.ac.id \\ Fitriah M. Suud \\ Universitas Serambi Mekkah \\ fitriahmsuud@gmail.com \\ Moh. Toriqul Chaer \\ STIT Islamiyah Karya Pembangunan Paron, Ngawi \\ toriqul_74@yahoo.com \\ Azam Syukur Rahmatullah \\ Universitas Muhammadiyah Yogyakarta \\ azamsyukurrahmatullah@yahoo.co.id
}

\begin{abstract}
Happiness is the essence of everyone's life. Its existence in itself has always been the driving force of man to do the best in his life. Civilization is constantly changing, but the happiness and meaningfulness of life remain the ultimate human choice of life. The industrial revolution 4 challenges people to do more quickly to achieve the quality of life through technology. The happiness education and meaningfulness of life are challenged to face the massive disruptions happening globally. In the end, the millennial generation as the holder of the industrial revolution 4 will be a superior generation of intelligent and qualified in running a global civilization. Live with a high level of intelligence that is comparable to quality life. This paper will present a discussion to open the higherorder thinking with a combination of the dimensions of religiosity and science as well as a healthy personality.
\end{abstract}

Keywords: Happiness, Industrial Revolution 4, Millenial Generation

\section{Pendahuluan}

Tantangan terbesar dalam era revolusi industri 4 adalah percepatan perubahan teknologi yang berpengaruh dalam setiap kehidupan. Diperlukan kematangan strategi sekaligus kekuatan mental untuk dapat bersaing dalam kompetisi global. Pendidikan dalam hal ini perlu melakukan terobosan dalam berbagai inovasi agar dapat melahirkan generasi bangsa yang cerdas, berkualitas dan kompetitif. ${ }^{1}$

1 "Pengembangan Iptek dan Pendidikan Tinggi di Era Revolusi Industri 4.0," ristekdikti (blog), accessed May 10, 2018, https://www.ristekdikti.go.id/pengembangan-iptek-dan-pendidikan-tinggi-diera-revolusi-industri-4-0/.

AL-MURABBI Vol. 5, No. 1, Juli 2018 ISSN 2406-775x (Print), ISSN 2540-7619 (Online) 
Era revolusi industri 4 melahirkan desrupsi secara massif yang berdampak pada persaingan ketat berbagai bidang, politik, ekonomi, pendidikan, sosial, hingga dogma agama. Enam hal yang mendorong kuat munculnya desrupsi adalah teknologi, generasi milenial, kecepatan microprosessor, desruptive leader, perubahan cara menang, dan internet of things. ${ }^{2}$ Renald Kasali menjelaskan bahwa gerakan generasi milenial dalam merespon revolusi industri 4 seperti bola salju yang terus menggelunding, semakin hari makin besar dan tanpa batas. ${ }^{3}$

Revolusi industri 4 menawarkan berbagai kemudahan yang murah, cepat, dan tanpa batas. Eksistensi manusia dalam mempertahankan rutinitas sosial ekonomi mulai dihadapkan pada perubahan global yang masif. Percepatan perubahan teknologi internet, kecerdasan buatan, dan big data mendorong setiap pihak untuk dapat berkompetisi dalam mencapai kehidupan yang lebih baik. Pemerintah terus berusaha untuk dapat mencapai target global dalam tekonologi, sosial, politik, dan ekonomi. ${ }^{4}$

Francis Fukuyama dalam bukunya, the Great Disruption: Human Nature and the Reconstitution of Social Order, menjelaskan bahwa transformasi masyarakat dari masyarakat pertanian kemudian menjadi masayarakat industrial dan masyarakat industri telah mebawa pengaruh yang luas dari perubahan sosial dalam sejarah manusia, yang disebutnya dengan istilah the great disruption. Hal ini dapat dijelaskan melalui penyebabnya, seperti kemiskinan dan ketimpangan, meningkatnya kekayaan yang

\footnotetext{
${ }^{2}$ Adi Wahyi Adji, “Bedahbukudisruption-170430165621.Pdf," accessed May 9, 2018, http://vnusantara.com/wp-content/uploads/2017/12/bedahbukudisruption-17043016562l.pdf.

3awaPos.com, "Millennials dan Disruption," accessed May 9, 2018 https://www.jawapos.com/read/2017/05/16/130348/millennials-dan-disruption. As a universal phenomenon and comparative, modernization according to Inkeles (1966) in his book The Modernization of Man, the modernization characterized a number of trends, including: (1) approve the idea of a new and daring test new methods and techniques, (2) the readiness expressed opinions, (3) oriented in the present and future than in the past, (4) appreciate timeliness, (5) planning, organization, and efficiency (6) see the world as it can in the calculation, (7) believe in science and technology, (8) see the importance of equitable justice, lihat Moh Toriqul Chaer, "The Deconstruction Of Character Education," International Journal of Technology And Business 1, no. 2 (2017): 56.

${ }^{4}$ Yongxin Liao et al., "The Impact of the Fourth Industrial Revolution: A Cross-Country/Region Comparison," Production 28 (2018), https://doi.org/10.1590/0103-6513.20180061.
} 
menyebabkan kondisi yang pertama, munculnya negara kesejahteraan modern, dan pergeseran budaya yang luas termasuk keruntuhan agama. ${ }^{5}$

Masyarakat kapitalist modern menurut Fukuyama, cenderung menghancurkan kekuatan modal sosial dalam masyarakat. Negara-negara maju atau industri telah mengabirkan kekuatan modal sosial tanpa memiliki kemampuan untuk membangunnya kembali. $^{6}$

Sejalan dengan Eric Formm 'masyarakat yang sakit'; apa yang dijelaskan oleh Fukuyama dapat ditemukan dalam penjelasan Jurgen Habermas tentang proyek modernitas yang belum selesai sebagai sebuah teori patologi modernitas. Menurut Habermas, rasionalitas telah menjadi karakteristik sistem sosial dalam bentuk yang berbeda, dan memiliki konflik dengan, rasionalitas yang menjadi ciri khas dunia kehidupan. Sistem sosial berkembang menjad kompleks, terdiferensiasi, terintegrasi, dan memiliki ciri khas nalar rasional. ${ }^{7}$ Keadaan ini, setiap orang akan mulai mempertanyakan tentang makna dan cara mencapai kebahagiaan, lantas apakah kebahagiaan juga akan mengalami desruptive innovation?

\section{Penelitian Terdahulu}

Tulisan tentang kebahagiaan telah banyak diuraikan dalam banyak literatur dengan berbagai pendekatan. Seligman dan Peterson adalah dua tokoh psikologi positif yang terkenal dalam menulis tentang kebahagiaan. Salah satu penelitiannya adalah Positive psychology progress: empirical validation of interventions. ${ }^{8}$ Penelitian ini menyebutkan bahwa ada tiga faktor utama yang mempengaruhi kebahagiaan terpenting dalam hidup seseorang. Ketiga faktor itu adalah faktor bawaan (set range), situasi lingkungan (circumstances), dan faktor yang terkait dengan keinginan seseorang yang dapat dikendalikan oleh seseorang. Jika hal ini dihubungkan dengan ajaran Islam maka jelas

${ }^{5}$ Francis Fukuyama, The Great Disruption: Human Nature and the Reconstitution of Social Order. Translation: Masri Maris, (Jakarta: PT Gramedia Pustaka Utama, 2005), 78-94.

${ }^{6}$ Francis Fukuyama, The Great Disruption: Human Nature,,.....307-308.

${ }^{7}$ Francis Fukuyama, The Great Disruption: Human Nature,,....307-308

${ }^{8}$ Seligman, M. E., Steen, T. A., Park, N., \& Peterson, C. (2005). Positive psychology progress: empirical validation of interventions. American psychologist, 60(5), 410. 
terlihat bahwa faktor kebersyukuran (gratitude) memiliki hubungan yang sangat erat dengan faktor ketiga yang telah disampaikan oleh Seligman di atas.

Penelitian lainnya yang masih terhitung baru adalah penelitian yang dilakukan oleh Shiota, M. N., Campos, B., Oveis, C.,e. ${ }^{9}$ Studi ini menunjukkan bahwa karyawan yang bekerja pada industri telekomunikasi dapat menangani stres pekerjaan mereka dengan peran moderasi kecerdasan emosional dan mengurangi efek stres kerja pada kepuasan hidup dan kebahagiaan. Penelitian ini memiliki hubungan erat dengan tulisan yang penulis uraikan dalam tulisan ini yaitu melihat kebahagiaan dalam dunia kerja dengan tingkat stres yang tinggi. Penelitian ini jika dianalisis dengan kaca mata Islam dan dengan pendekatan psikologi positif ${ }^{10}$ akan bertemu pada memahami kebermaknaan hidup dan tingkat kepuasan hidup yang perlu ditanamkan pada setiap manusia sekarang ini.

Selanjutnya penelitian-penelitian yang berhubungan dengan kebahagiaan dan Islam telah banyak diuraikan dalam berbagai literatur. Bahkan skala pengukuran kebahagiaan juga telah mulai di susun. Sahriann et al. 2013 ${ }^{11}$ membuat kuesiner tentang sikap agama, Achur dkk ${ }^{12}$ membuat skala religiusitas dan kekuatan dari diri manusia. Abdel-Khalek $2010^{13}$ menghubungkan keyakinan beragama dengan kebahagiaan, Achour et al. $2017^{14}$ komitmen keagamaan, dan Haque 2004 hubungan antara kebahagiaan dan Islam secara lebih luas. Ini artinya bahwa agama

${ }^{9}$ Shiota, M. N., Campos, B., Oveis, C., Hertenstein, M. J., Simon-Thomas, E., \& Keltner, D. (2017). Beyond happiness: Building a science of discrete positive emotions. American Psychologist, 72(7), 617.

${ }^{10}$ Seligman, M. E., \& Csikszentmihalyi, M. (2014). Positive psychology: An introduction. In Flow and the foundations of positive psychology (pp. 279-298). Springer Netherlands.

${ }^{11}$ Sahraian, A., Gholami, A., Javadpour, A., \& Omidvar, B. (2013). Association between religiosity and happiness among a group of Muslim undergraduate students. Journal of Religion and Health, 52(2), 450-453. https://doi.org/10.1007/s10943-011-9484-6

${ }^{12}$ Achour, M., Nor, M. R. M., \& Yusoff, M. Y. Z. M. (2015). Work-family demands and subjective well-being among female academicians: The role of Muslim Religiosity. Review of Religious Research, 57(3), 419-433. https://doi.org/10.1007/s13644-015-0221-6. educational level as moderator. Journal of Religion and Health. https://doi.org/10.1007/s10943-017-0361-9.

${ }_{13}$ Abdel-Khalek, A. M. (2010). Quality of life, subjective well-being, and religiosity in Muslim college students. Quality of Life Research, 19(8), 1133-1143. https://doi.org/10.1007/sll136-010-9676-7

${ }^{14}$ Achour, M., Nor, M. R. M., Amel, B., Seman, H. M. B., \& MohdYusoff, M. Y. Z. (2017). Religious commitment and its relation to happiness among Muslim students: The.

${ }^{15}$ Haque, A. (2004). Religion and mental health: The case of American Muslims. Journal of Religion and Health, 43(1), 45-58

${ }^{16}$ Joshanloo, M. (2013). A comparison of Western and Islamic conceptions of happiness. Journal of Happiness Studies, 14(6), 1857-1874. https://doi.org/10.1007/s10902-012-9406-7. 
memiliki hubungan yang erat dengan kebahagiaan seseorang. Semakin tinggi tingkat religiusitas seseorang maka akan tinggi kesempatan untuk seseorang untuk berbahagia. Namun pertanyaannya adalah apakah kebahagiaan di era revolusi industri 4 memiliki tantangan sendiri?.

\section{Tujuan dan Metode Penelitian}

Secara keseluruhan tujuan dari tulisan ini adalah untuk melihat tingkat kebahagiaan di era evolusi industri 4 dan mengajukan metode pendidikan kebahagiaan yang tepat untuk dapat meningkatkan kebahagiaan human being di zaman industri ini. Dalam mencapai tujuan tersebut maka tulisan ini melakukan langkah-langkah tertentu secara ilmiah. Studi literatur dilakukan dengan melihat, mengkaji dan menganalisis literatur-literatur dalam berbagai perspektif yang berhubungan dengan kebahagiaan sebagaimana yang telah disebutkan dalam prior of research.

Beberapa literatur yang serasi tepat dan memiliki hubungan yang erat akan dipilih dan disajikan dalam sebuah teori untuk mengeluarkan sebuah metode yang tepat yang dapat digunakan pada era ini. Tulisan ini merupakan perpaduan pemikiran psikologi positif dan psikologi Islam serta menggabungkan dengan beberapa disiplin ilmu yang saling berhubungan. Sistem kerja ini berpedoman pada metode integrasi dan interkoneksi keilmuan yang ditawarkan oleh Amin Abdullah. ${ }^{17}$ Bahwa pada era ini diperlukan berbagai pendekatan yang mampu memecah kebekuan dan kejenuhan disiplin ilmu yang berdiri sendiri-sendiri dan mampu melunakkan batas-batas kaku antara berbagai disiplin ilmu. Demikian pula dengan kebahagiaan di zaman revolusi industri 4 ini perlu dilihat dari berbagai pendekatan.

Sementara untuk perpaduan kajian keilmuan khusus psikologi Islam, dalam tulisan ini merujuk pada pedoman integrasi psikologi positif dan psikologi Islam yang di tawarkan oleh tokoh psikologi Islam Indonesia yaitu Abdul Majid. ${ }^{18}$ Secara sederhana

\footnotetext{
${ }^{17}$ Abdullah, M. A., \& Abdullah, M. A. (2007). Islamic studies dalam paradigma integrasi interkoneksi: sebuah antologi. Suka Press.

${ }^{18}$ Mujib, A., \& Mudzakir, J. (2001). Nuasa-nuasa psikologi Islam. Raja Grafindo Persada. Mujib, H. A. (2006). Kepribadian dalam psikologi Islam. PT Rajagrafindo Persada.Mujib, A., \& Daradjat, Z. (1999). Fitrah dan kepribadian Islam: sebuah pendekatan psikologis. Darul Falah.
} 
pola perpaduan metode yang ditawarkan adalah pola idealistis dan pola pragmatis. Kedua pola tersebut dalam digambarkan sebagai berikut:

Tabel 1.

Metode Psikologi Islam Pola Idealistik dan Pola Pragmatis

\begin{tabular}{|l|l|}
\hline Pola Idealistik & Pola Pragmatis \\
\hline$>$ Digali dari khazanah Islam & $\begin{array}{l}>\text { Mengutamakan aspek praktis dan } \\
\text { kegunaannya }\end{array}$ \\
\hline$>$ Pangkal studi dari studi Islam & $>$ Diadopsi dari teori-teori psikologi Barat \\
\hline$>\begin{array}{l}\text { Pola ini menggunakan metode deduktif dari } \\
\text { ayat-ayat qawliyyah. }\end{array}$ & $>$ Dijustivikasi dengan al-nash (Islamisasi) \\
\hline$>\begin{array}{l}\text { Melalui pola ini maka tercipta apa yang disebut } \\
\text { dengan Psikologi Islam }\end{array}$ & $\begin{array}{l}>\text { Metode ini menghasilkan rumusan } \\
\text { Psikologi Islami (dengan huruf 'i' pada kata } \\
\text { Islam). }\end{array}$ \\
\hline
\end{tabular}

\section{Pembahasan}

\section{Kebahagiaan dan Revolusi Industri 4}

Eksistensi kebahagiaan akan terus ada dalam diri setiap orang, karena kebahagiaan menjadi kebutuhan utama dalam kehidupan. Kebahagiaan hakiki muncul disaat pribadi menjalani kebaikan. Karena potensi kebaikan yang ada pada setiap manusia sangat berpengaruh terhadap munculnya kebahagiaan. ${ }^{19}$ Kebahagiaan akan terus menguat jika setiap orang mampu mengontrol kondisi eksternal menjadi intervensi positif. ${ }^{20}$ Kebahagiaan-kebahagiaan yang terjadi secara berkelanjutan pada akhirnya mampu merubah seseorang menjadi pribadi yang optimis dalam menjalani kehidupan. ${ }^{21}$ Sikap positif yang terus dikembangkan ini merupakan modal utama manusia untuk bertahan dalam kondisi zaman apapun.

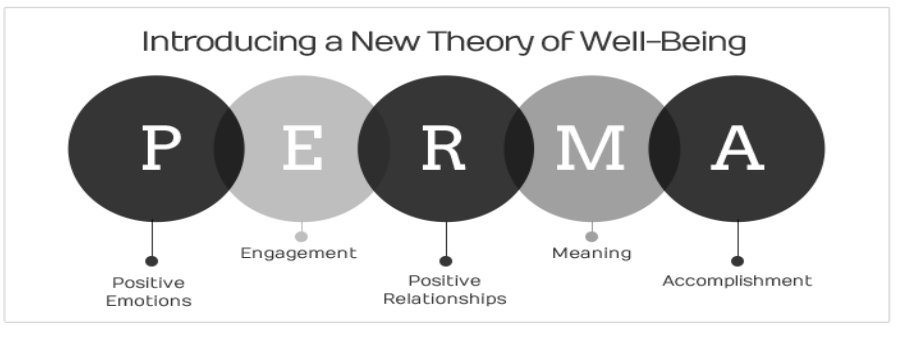

\footnotetext{
${ }^{19}$ Martin E. P. Seligman, "Seligman-PosPsychProgress.Pdf," n.d.

20 Martin E. P. Seligman et al., "Positive Psychology Progress: Empirical Validation of Interventions.," American Psychologist 60, no. 5 (2005): 410-21, https://doi.org/10.1037/0003-066X.60.5.410.

${ }^{21}$ Martin E. P. Seligman, "Martin Seligman_Learned Optimism.Pdf," n.d.
} 
Gambar 1.

Teori Baru Kesejahteraan Martine Seligman ${ }^{22}$

Bahagia tidak lagi dalam level kesenangan, namun lebih tinggi yaitu tentang kebahagiaan autentik dan kebermaknaan hidup. Seligman menjelaskan bahwa kebahagiaan merupakan inti dari psikologi positif, sedangkan kesejahteraan merupakan kebermaknaan hidup. Kolom di bawah ini bisa menjelaskan tetang perbedaan dua hal tersebut, yaitu kebahagiaan yang autentik dan kesejahteraan.

Tabel 2.

Perbedaan Teori Kebahagiaan Autentik dan Kesejahteraan

\begin{tabular}{|l|l|l|}
\hline & $\begin{array}{l}\text { Authentic } \\
\text { Happiness Theory }\end{array}$ & Well-Being Theory \\
\hline Topic & Happiness & Well-Being \\
\hline Measure & Life satisfaction & $\begin{array}{l}\text { Positive emotion, engagement, positive relationships, } \\
\text { meaning, and accomplishment }\end{array}$ \\
\hline Goal & Increase life satisfaction & $\begin{array}{l}\text { Increase flourishing by increasing positive emotion, } \\
\text { engagement, positive relationships, meaning, and } \\
\text { accomplishment }\end{array}$ \\
\hline
\end{tabular}

Teori kebahagiaan ini merupakan bentuk pilihan setiap orang untuk mendapatkan kebahagiaannya sendiri berbasis kesenangan yang bebas ia pilih. Kebahagiaan menjadi gambaran dari bentuk kondisi perasaan yang menyenangkan. Teori kesejahteraan lebih dari teori kebahagiaan, yaitu melibatkan suasana perasaan, pikiran, dan kebermaknaan dalam hidup. Tidak hanya bahagia sesuai dengan perspektif pikiran masing-masing, tetapi lebih melibatkan kombinasi dari berbagai suasana diri dan berbentuk nyata pada aspek eksternal diri. ${ }^{23}$

Tantangan kebahagiaan dan kebermaknaan hidup setiap orang pada akhirnya dihadapkan pada eksternal diri, yaitu peradaban baru yang disebut sebagai revolusi industri 4. Mayoritas pemegang revolusi industri 4 adalah kaum muda yang sering disebut dengan generasi milenial. Cepat, murah, canggih, terbuka, adalah diantara

22 "Positive Psychology Initiatives | Authentic Happiness," accessed May 10, 2018, https://www.authentichappiness.sas.upenn.edu/learn.

23 "What Is Well-Being? | Authentic Happiness," accessed May 10, 2018, https://www.authentichappiness.sas.upenn.edu/learn/wellbeing.

AL-MURABBI Vol. 5, No. 1, Juli 2018 ISSN 2406-775x (Print), ISSN 2540-7619 (Online) 
sekian banyak indikasi era revolusi industri 4 yang tidak menutup kemungkinan akan mengganggu kehidupan manusia. ${ }^{24}$ Tuntutannya begitu menantang untuk terus bergerak cepat dalam perubahan, terjadi desruptif secara masif ${ }^{25}$ yang tidak bisa lagi dibendung. Sementara kebahagiaan tetap menjadi pilihan sekaligus tujuan akhir setiap orang untuk memiliki hidup yang lebih bermakna. Generasi milenial yang lebih terbuka, toleran sekaligus multikultural, bersemangat dengan tantangan, tidak fanatik, ${ }^{26}$ dan keberagaman yang multidisiplin ${ }^{27}$ dimungkinkan lebih memiliki kesempatan untuk mendapatkan kehiduan yang berkualitas.

Dalam bidang pekerjaan generasi milenial lebih mampu menyesuaikan diri dengan target-target perusahaan yang telah berdaptasi dengan revolusi industri 4. Kemampuan diri dalam beradaptasi mampu mendatangkan kebahagiaan seiring dengan aktifitas mereka di internet melalui media sosial. ${ }^{28}$ Semangat, mencapai target untuk reward, ${ }^{29}$ abisius, dan berani mengambil resiko adalah beberapa ciri generasi milenial dalam budaya kerja. Mereka lebih siap untuk mendapatkan kebahagiaan dengan cepat selama reward dalam pekerjaan sesuai dengan harapan. Seorang pimpinan yang senior diharapkan mampu menyeimbangkan faktor-faktor yang menjadi penyebab munculnya loyalitas dalam pekerjaan. ${ }^{30}$

${ }^{24}$ Alin Stăncioiu, "The Fourth Industrial Revolution „Industry 4.0”.Pdf,” accessed May 9, 2018, http://www.utgiiu.ro/rev_mec/mecanica/pdf/201701/ll_Alin\%20ST\%C4\%82ncioiu\%20\%20the\%20fourth $\% 20$ industrial\%20revolution\%20\%E2\%80\%9eindustry\%204.0\%E2\%80\%9D.pdf.

${ }^{25}$ aspirasi, "Prof Clayton M. Christensen: Disruptive Innovation," September 6, 2017, http://kumpulanstudi-aspirasi.com/ekonomi/prof-clayton-m-christensen-disruptive-innovation/; Budi Agus Riswandi, "2017-07-27-Fh-Uii-Semnas-Inovasi-Teknologi-Dan-Hak-Kekayaan-IntelektualFenomena-Disruptive-Innovation-Budi-Agus-Riswandi-Word.Pdf," accessed May 9, 2018, https:/law.uii.ac.id/wp-content/uploads/2017/07/2017-07-27-fh-uii-semnas-inovasi-teknologi-dan-hakkekayaan-intelektual-fenomena-disruptive-innovation-budi-agus-riswandi-word.pdf.

${ }^{26}$ Wahyudi Setiawan, "Fanatisme Dalam Berorganisasi," n.d., 25.

${ }^{27}$ Sky Brown et al., "Generation Y in the Workplace," n.d., 79.

28 Debashish Sengupta, "Pmwj45-Apr2016-Sengupta-Investigating-Happiness-of-GenerationyMillennials-Featured-Paper.Pdf," accessed May 9, 2018, https://pmworldjournal.net/wpcontent/uploads/2016/04/pmwj45-Apr2016-Sengupta-investigating-happiness-of-generationymillennials-featured-paper.pdf.

${ }^{29}$ Wahyudi Setiawan, "Reward and Punishment dalam Perspektif Pendidikan Islam," n.d., 18.

${ }^{30}$ Veronika Kuchárová Mačkayová And Veronika Baláţová, "Characteristics Of Generation Y And Its Future Occupation - Comparison Of Opinions," Human Resources Management l (n.d.): 16; Agnieszka Stanimir, "Generation Y - Characteristics of Attitudes on Labour Market," Mediterranean Journal of Social Sciences, April 1, 2015, https://doi.org/10.5901/mjss.2015.v6n2s5p22. 
Era revolusi industri 4 lebih memudahkan generasi milenial untuk membangun persahabatan yang tanpa batas. Jaringan yang berhasil dibentuk misalnya melalui media sosial facebook sangat bermanfaat untuk menjadi media mereka untuk menunjukkan jati diri. Media sosial sekaligus mampu mampu menjadi modal untuk mendapatkan kebahagiaan. ${ }^{31}$ Aktifitas generasi milenial lebih banyak dalam internet, sehingga menuntut setiap elemen untuk mampu menyesuaikan diri. Ketidakmampuan pemain lama dalam menyesuaikan diri dengan generasi milenial dipastikan akan ditinggal, mereka lebih memilih segala sesuatu yang mampu menghadirkan diri secara cepat.

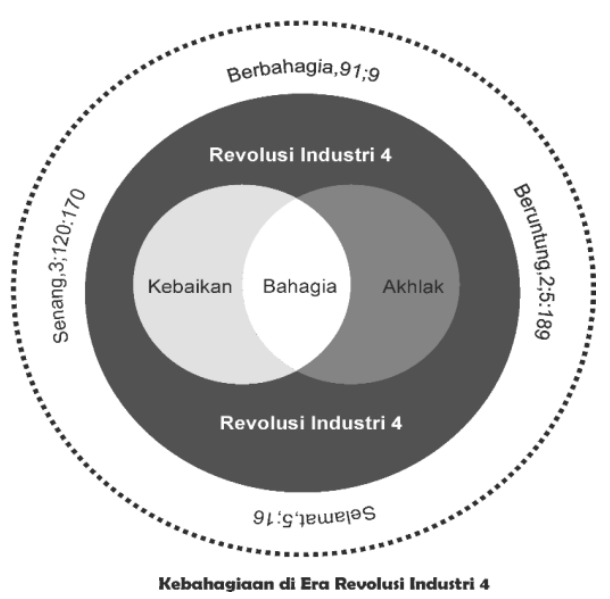

Gambar 2.

Kebahagiaan di Era Revolusi Industri 4

\section{Al-Qurân dan Kebahagiaan Zaman Milenial}

Kebahagiaan tidak berhenti dalam wilayah lahiriah batiniah sesuai dengan penemuan manusia. Dalam Al Quran kebahagiaan dituliskan dengan menggunakan beberapa makna yaitu dengan istilah selamat, beruntung, berbahagian, dan tenteram. Istilah ini hanya perwakilan dari sekian banyak istilah dalam Al Quran yang menjelaskan tentang betapa pentingnya kebahagiaan seseorang. Aspek kebahagiaan lahir dan batin selama hidup di dunia harus menjadi perhatian utama selama dalam lingkup kebaikan.

\footnotetext{
${ }^{31}$ Adriana M. Manago and Lanen Vaughn, "Social Media, Friendship, and Happiness in the Millennial Generation," in Friendship and Happiness, ed. Melikşah Demir (Dordrecht: Springer Netherlands, 2015), 187-206, https://doi.org/10.1007/978-94-017-9603-3_ll; Efstratia Arampatzi, Martijn J. Burger, and Natallia Novik, "Social Network Sites, Individual Social Capital and Happiness," Journal of Happiness Studies, October 20, 2016, 1-24, https://doi.org/10.1007/s10902-016-9808-z.
} 
Selanjutnya kebahagiaan tidak berhenti selama kehidupan di dunia, tetapi harus berlanjut setelah kematian yaitu kebahagiaan di akhirat.

Revolusi industri 4 yang serba canggih dalam teknologi harus berada dalam kontrol akhlak dan perbuatan baik manusia. Hal ini dikarenakan kecanggihan teknologi misalnya kecerdasan buatan dan internet, jika tidak dikendalikan oleh pribadi yang baik maka akan mampu menimbulkan keburukan bagi diri dan orang lain. Kendali diri berupa akhlak dan kebaikan adalah pondasi untuk memunculkan kebahagiaan hakiki tanpa terpengaruh oleh eksternal. Kebahagiaan ini yang akan mampu menjadikan revolusi industri 4 sebagai gurun teknologi dalam mendulang kebermanfaatan global untuk umat. Selanjutnya kebahagiaan pribadi dalam era revolusi industri 4 akan mampu menjadikan kehidupan umat menjadi selamat, beruntung, berbahagia, dan tenteram.

Beberapa contoh ayat Al Quran yang menjelaskan tentang simbol-simbol kebahagiaan adalah sebagai berikut; "Sesungguhnya beruntunglah orang yang mensucikan jiwa itu" (QS. Asy Syams (91): 9). M. Quraish Syihab dalam ayat ini menjelaskan bahwa orang-orang yang senantiasa mensucikan jiwanya dengan terus berbuat baik, sesungguhnya beruntung dan berbahagialah mereka. "Mereka itulah yang tetap mendapat petunjuk dari Tuhan mereka, dan merekalah orang-orang yang beruntung" (QS Al-Baqarah (2): 5). Mereka adalah golongan orang-orang yang ditetapkan ciri-cirinya untuk mendapatkan petunjuk ketuhanan. Mereka adalah golongan orang yang mendapatkan kemenangan, yaitu pahala yang diharapkan dan didambakan karena buah dari kerja keras mereka dalam ketaatan dengan menjalankan perintah dan menjauhi larangan Tuhan. "......kebajikan itu adalah kebajikan orang-orang yang bertakwa. Dan masuklah ke rumah-rumah itu dari pintu-pintunya, dan bertakwalah kepada Allah supaya kamu beruntung" (QS. Al-Baqarah: 189).

"Jika kamu memperoleh kebaikan, niscaya mereka bersedih hati, tetapi Jika kamu mendapat bencana, mereka bergembira karenanya. Jika kamu bersabar dan bertakwa, niscaya tipu daya mereka sedikitpun tidak mendatangkan kemudharatan kepadamu. Sesungguhnya Allah mengetahui segala apa yang mereka kerjakan" (QS. Ali Imran: 120). 
"Mereka dalam keadaan gembira disebabkan karunia Allah yang diberikan-Nya kepada mereka, dan mereka bergirang hati terhadap orang-orang yang masih tinggal di belakang yang belum menyusul mereka, bahwa tidak ada kekhawatiran terhadap mereka dan tidak (pula) mereka bersedih hati" (QS. Ali Imran: 170). Dari kedua ayat tersebut telah menyebutkan kata senang dalam diri manusia. Setiap manusia pasti merasakan kesenangan dalam dirinya, tetapi masingmasing kesenangan akan memiliki ketentuan sendiri sesuai dengan kesenangan yang manusia rasakan. Bukan saja disaat manusia terjaga dalam merasakan kebahagiaan, tetapi disaat ia tertidur dan mimpi ${ }^{32}$ manusia tetap hidup dialamnya.

"Dengan kitab itulah Allah menunjuki orang-orang yang mengikuti keridhaan-Nya ke jalan keselamatan, dan (dengan kitab itu pula) Allah mengeluarkan orang-orang itu dari gelap gulita kepada cahaya yang terang benderang dengan seizin-Nya, dan menunjuki mereka ke jalan yang lurus" (Al Maidah, 5;16). M. Quraish Syihab menjelaskan bahwa melalui Al Quran Allah telah memberikan petunjuk kepada orang-orang yang mengharapkan keridaan-Nya menuju jalan keselamatan, serta mengeluarkan mereka dari gelapnya kekufuran kepada terangnya cahaya keimanan dan memberinya petunjuk ke jalan yang benar. ${ }^{33}$

\section{Pendidikan Kebahagiaan Generasi Milenial}

Generasi milenial sangat menghargai perbedaan, lebih memilih kerjasama dan pragmatis dalam menghadapi persoalan. Mereka memiliki rasa optimis yang tinggi dan berorientasi pada prestasi, percaya diri pada nilai moral dan sosial serta menghargai keragaman. ${ }^{34}$ Orientasi belajar mereka menggunakan media internet yang super cepat dan memberikan segala informasi yang dibutuhkan. ${ }^{35}$ Eksistensi mereka semakin nyata ditengah globalisasi teknologi digital yang terus berkembang. Mereka adalah aktor sekaligus pengembang teknologi di era revolusi industri 4 yang bergerak masif disetiap bidang kehidupan. Misalnya di Indonesia berkembang bisnis digital seperti bukalapak,

${ }^{32}$ Wahyudi Setiawan, “Al-Qur'an Tentang Lupa, Tidur, Mimpi Dan Kematian” 2 (2016): 20.

33 "Al-Quran Online Bahasa Indonesia | Tafsirq.Com," accessed May 1l, 2018, https://tafsirq.com/.

${ }^{34}$ Yanuar Surya Putra, "Teori Perbedaan Generasi," 2016, 12.

${ }^{35}$ Arlene J. Nicholas, "Preferred Learning Methods of the Millennial Generation," The International Journal of Learning: Annual Review 15, no. 6 (2008): 27-34, https://doi.org/10.18848/14479494/CGP/vl5i06/45805. 
tokopedia, dan lazada sebagai pioner market place. Bisnis jasa trasportasi ada gojek, tiket.com adalah contoh dari sekian banyaknya pergerakan bisnis digital yang dinahkodai oleh generasi muda.

Penelitian di Republik Ceko dan Slovakia, dua negara di wilayah Eropa telah teridentifikasi tentang perilaku bersenang-senang bagi generasi milenia. Mereka lebih suka dengan belanja berbagai merk tertentu sebagai simbol sosial pergaulan. Generasi muda disana merasa bahagia dengan membelanjakan uangnya untuk barang-barang seperti pakaian dan elektronik. Merk menjadi identitas sosial dan penjamin kualitas yang penting, sementara harga diskon adalah sesuatu yang menyenangkan tersendiri bagi mereka. Segmentasi media belanja ada dua, yaitu online dan offline. ${ }^{36}$ Perilaku seperti ini banyak dijumpai dikalangan generasi muda saat ini. ${ }^{37}$

Tantangan bagi setiap pendidik untuk menanamkan nilai budi pekerti dan pemahaman tentang makna kebahagiaan pada generasi muda. Pemahaman dan pemaknaan harus tepat sehingga perilaku kehidupan generai $Y$ dan $Z$ sebagai pelaku utama revolusi industri 4 memiliki kehidupan yang bermakna. Generasi milenial lebih bebas menentukan hidupnya sendiri termasuk dalam memaknai dan mencapai kebahagiaan. Eksistensi mereka di era revolusi industri 4 menantang mereka untuk menentukan secara bebas untuk menjadi entrepreneur, freelance, atau join dengan star-up.

Kecepatan informasi dan teknologi mengantarkan mereka pada dunia baru yang serba canggih, sehingga kebermaknaan hidup seolah hanya diukur dengan menggunakan materi. Pertumbuhan ekonomi yang semakin meningkat tidak menjadikan mereka bergantung kepada keadaan, namun lebih pada eksplorasi diri untuk mencari pengalaman dan menemukan dirinya sendiri.

${ }^{36}$ VSB - Technical University of Ostrava and Petra Klapilova Krbova, "Generation Y Attitudes towards Shopping: A Comparison of the Czech Republic and Slovakia," Journal of Competitiveness 8, no. 1 (March 31, 2016): 38-54, https://doi.org/10.7441/joc.2016.01.03.

37 Kompasiana.com, "Mall, Jadi Gaya Hidup?," KOMPASIANA, accessed May 11, 2018, https://www.kompasiana.com/richardo/mall-jadi-gaya-hidup_55010149a3331135195107b5; "Jalan-jalan Sekalian Shoping ke Mal," Tribun Pekanbaru, accessed May ll, 2018, http://pekanbaru.tribunnews.com/2017/01/30/jalan-jalan-sekalian-shoping-ke-mal. 


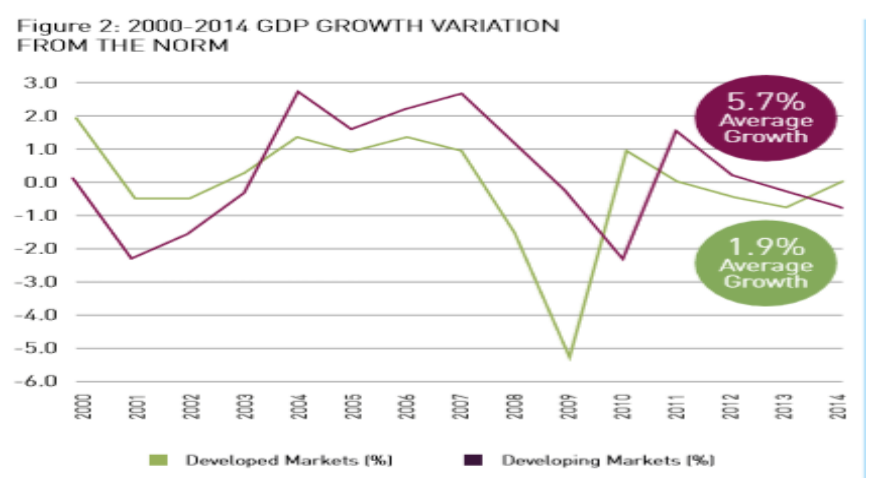

Grafik 1 .

Pertumbuhan Ekonomi Negera Maju

Disisi lain generasi milenial lebih bersemangat untuk menambah pengalaman mereka sebanyak-banyaknya dibandingkan dengan mendapatkan kesenangan secara material. Mereka menyadari bahwa kerja saja tidaklah cukup, mereka membutuhkan relasi sosial sebagai media untuk mengekspresikan diri dalam keberagaman kehidupan yang semakin komplek. Sarana mereka adalah dengan menggunakan media sosial internet untuk menjalin hubungan dan mengembangkan jaringan. Misalnya terdapat kelompok generasi milenial di Cina dan Australia yang lebih cenderung pada tindakan altruisme untuk mendapatkan kebermaknaan hidup. Mereka mendapatkan kebahagiaan dan kebermaknaan hidup dengan cara mensejahterakan orang lain dan melihat orang lain bahagia. Kebahagiaan mereka muncul disaat mereka dapat menjadikan orang lain bahagia. ${ }^{38}$

Peningkatan kesadaran generasi milenial terhadap kebermaknaan hidup menjadi nilai plus untuk menciptakan peradaban global yang lebih baik. Dalam pendidikan Islam, Al Ghazali menjelaskan bahwa kebahagiaan harus disadari oleh setiap orang. Makna kebahagiaannya akan menggerakkan badannya untuk mencapai kebahagiaan yang ia inginkan. Masing-masing indera dalam tubuh manusia memiliki kesenangan sendiri. Misalnya lidah merasa bahagia dengan mengecap rasa yang enak. Mata akan bahagia dengan melihat obyek yang indah, telinga mendapatkan kebahagiaannya dengan mendengar musik yang indah. Segala sesuatu akan mencapai kebahagiaannya

38.02-Report-The-Pursuit-Of-Happiness.Pdf," accessed May 9, 2018, http://youmark.it/wpcontent/uploads/2014/12/02-Report-The-Pursuit-Of-Happiness.pdf. 
sesuai dengan sifatnya. Hati dan pikiran akan mendapatkan kebahagiaan jika apa yang ia rasa dan pikirkan tercapai sesuai dengan apa yang diharapkan. ${ }^{39}$

Pendidikan kebahagiaan adalah pendidikan penanaman akhlak dan budi pekerti luhur terhadap generasi milenial. Persaingan yang ketat di era revolusi industri 4 menjadikan posisi akhlak menjadi sangat penting untuk kehidupan. Kecanggihan teknologi seakan menjadi tuhan-tuhan baru bagi manusia karena ketergantungan yang tinggi dalam setiap aktifitas. Keutamaan kebahagiaan adalah keutamaan akhlak dalam setiap pribadi manusia. Kebahagiaan hakiki akan muncul disaat kebaikan dilakukan dalam kehidupan. Kebahagiaan inderawi terbatas pada kelezatan inderawi sesuai dengan sifatnya, tetap kebahagiaan hati dan pikiran adalah kebahagiaan yang muncul karena kebaikan lahir dan batin yang dilakukan manusia. Misalnya UN tahun 2017 telah merilis indeks kebahagiaan masyarakat dunia seperti gambar berikut di bawah ini, dimana Indonesia menempati nomor 79 yang bahagia dari 157 negara.

${ }^{39} \mathrm{Abu}$ Hamid al-Ghazali, Kimiya Al-Sa'adah (Kairo: Mathba'at al-Sa'adat, 1934), http://www.penerbitzaman. com download/Kimia-Ruhani-untuk-Kebahagiaan-Abadi.pdf. 

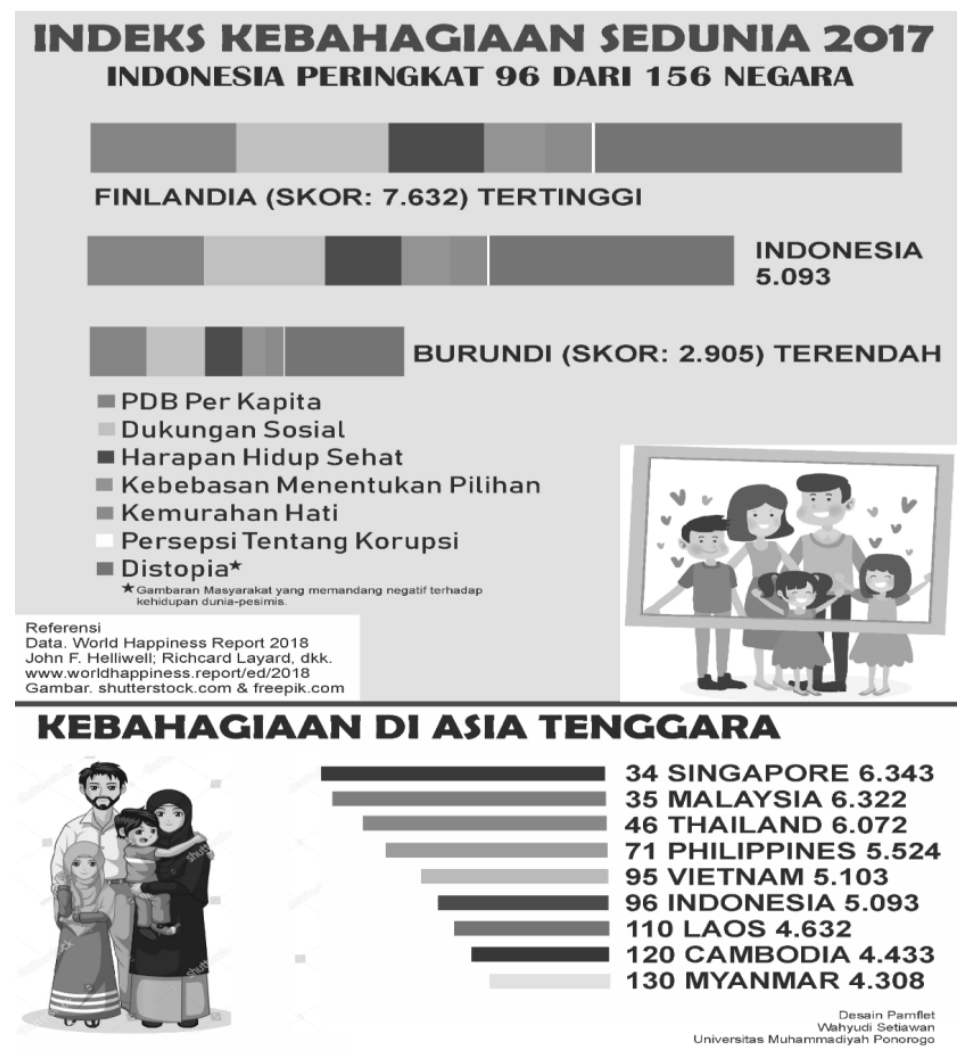

Gambar 3.

Indeks Kebahagiaan Masyarakat Dunia ${ }^{40}$

Indonesia yang menempati urutan ke 96 indeks kebahagiaan dunia, merupakan simbol bahwa sesungguhnya pemaknaan dan pencapain kebahagiaan masyarakat Indonesia harus diperhatikan. Data yang ditunjukkan adalah simbil tentang kondisi psikologis yang harus terus ditingkatkan seiring dengan perhatian pemerintah Indonesia untuk meningkatkan perekonomian nasional. Penyeimbangan kebutuhan materi dan psikologis menjadi penting untuk mendapatkan kualitas dan kebermaknaan hidup. Disamping manusia harus terus bekerja keras untuk peningkatan kebutuhan sosial dan meterial, kebahagiaan harus diposisikan sebagai tujuan utama. Pendidikan kebahagiaan dalam lingkungan keluarga dan sekolah, menanamkan nilai kebaikan dan akhlak adalah upaya nyata bahwa bekal kebagusan budi pekerti menjadi modal utama dalam menghadapi era revolusi industri 4.

\footnotetext{
40"Peringkat Kebahagiaan Indonesia Di Tengah," accessed May 1l, 2018, https://beritagar.id/artikel/infografik/ peringkat-kebahagiaan-indonesia-di-tengah.
}

AL-MURABBI Vol. 5, No. 1, Juli 2018 ISSN 2406-775x (Print), ISSN 2540-7619 (Online) 


\section{Kontribusi Terhadap Ilmu Pengetahuan}

Perubahan zaman pasti terjadi namun Islam adalah agama yang tetap serasi dan tepat untuk setiap zaman. Al Quran merupakan hudan yang dapat digunakan setiap masa tanpa batas. Tidak pernah ada perubahan ayat-ayat dalam Al Quran tetapi perubahan zaman menuntut akan adanya tingkat berfikir manusia yang tinggi, nalar yang luar dan kepekaan sosial yang sensitif. Bicara kebahagiaan bagi umat dizaman milenial bukanlah sebuah ketakutan jika masih menjadikan Al Quran sebagai hudan dan tidak menjadi pribadi yang "latah". Kepribadian yang sehat dalam Islam adalah pribadi yang bertaqwa dalam makna menjalankan kebenaran dan kebaikan serta menghindari diri dari semua larangan.

Perjalanan dan kondisi saat ini tentu saja tidak cukup hanya dengan memberikan pengetahuan tentang kebaikan dan kebenaran karena ini baru masuk pada ranah kognitif atau knowing. Ada dua ranah lagi yang perlu diperhatikan yaitu afektif dan psikomotor yang dalam bahasan pendidikan karakter dikenal dengan istilah moral feeling dan moral action. Sehingga dalam era revolusi industri ini pendidikan kebahagiaan perlu memperhatikan ketiga ranah tersebut. Berbagai fasilitas dan koneksi tak terbatas di dunia maya dapat dijadikan sarana untuk membangun karakter siswa. Arus informasi yang tidak terbentuk pasti memiliki nilai-nilai positif dan negatif. Sehingga teknologi dan informasi sebisa mungkin dimanfaat dengan tepat kearah positif oleh seorang pendidik dengan metode Pendidikan yang tepat dan kontekstual.

Selain memperhatikan metode Pendidikan kebahagiaan di atas. Perlu aksi lain yang dapat membantu pelajar baik ditingkat sekolah maupun ditingkat universitas. Ada tiga kunci penting yang perlu diperhatikan dalam menghadapi revolusi industry 4 yaitu: yang pertama adalah memperkenalkan General Education. Saling keterkaitan antara keterampilan berpikir ilmiah (scientific skill) dan pemikiran kemanusiaan (humanistic thought), humanities and social sciences untuk pembentukan karakter yang kuat. Kedua adalah memperhatikan multi,-inter-, dan transdisiplin, artinya tidak menutup diri 
dengan berbagai informasi diluar ranah keilmuan individu. Terakhir yang terpenting adalah adanya kajian Islam yang membumi dalam praktisnya dalam proses Pendidikan.

\section{Catatan Akhir}

Kebahagiaan telah menjadi isu yang krusial, tidak hanya dalam kajian filsafat etika, tetapi juga psikologi dan agama. Banyak ajaran hidup bahagia dijelaskan melalui teori-teori psikologi maupun filsafat, tetapi semuanya terbukti tidak mampu mengatasi krisis kebahagiaan manusia modern, jika tidak disebut gagal membawa kebahagiaan bagi penganutnya. Problem ini disebabkan kebahagiaan yang dijelaskan dalam psikologi empiris hanya menyentuh wilayah yang teramati (observable area).

Era revolusi industri 4 yang menawarkan kemudahan dan kecepatan menjadikan manusia berubah menjadi super cepat. Teknologi digunakan dan dikembangkan untuk mempercepat capaian setiap tujuan yang telah ditentukan manusia. Pada akhirnya kebutuhan materi dan psikologis menjadi keniscayaan untuk dilupakan, justru akan semakin bertambah.

Eksistensi kebutuhan manusia untuk bahagia merupakan bagian terpenting yang harus diperhatikan. Pendidikan kebahagiaan dalam mencapai kebahagiaan hakiki merupakan hal terpenting yang harus menjadi perhatian utama. Pendidikan kebahagiaan adalah pendidikan kebaikan dan akhlak yang harus diutamakan dan ditekankan, karena hanya dengan kebaikan dan akhlak manusia akan mampu mencapai kebahagiaan hakiki.

\section{Daftar Rujukan}

"02-Report-The-Pursuit-Of-Happiness.Pdf." Accessed May 9, 2018. http://youmark.it/wp-content/uploads/2014/12/02-Report-The-Pursuit-OfHappiness.pdf.

Abdel-Khalek, A. M. (2010). Quality of life, subjective well-being, and religiosity in Muslim college students. Quality of Life Research, 19(8), 1133-1143. https://doi.org/10.1007/s11136-010-9676-7

Abdullah, M. A., \& Abdullah, M. A. (2007). Islamic studies dalam paradigma integrasi interkoneksi: sebuah antologi. Suka Press.

Achour, M., Nor, M. R. M., \& Yusoff, M. Y. Z. M. (2015). Work-family demands and subjective well-being among female academicians: The role of Muslim 
Religiosity. Review of Religious Research, 57(3), 419-433. https://doi.org/10.1007/s13644-015-0221-6. educational level as moderator. Journal of Religion and Health. https://doi.org/10.1007/s10943-017-0361-9.

Achour, M., Nor, M. R. M., Amel, B., Seman, H. M. B., \& MohdYusoff, M. Y. Z. (2017). Religious commitment and its relation to happiness among Muslim students

Adi Wahyi Adji. "Bedahbukudisruption-170430165621.Pdf." Accessed May 9, 2018. http://vnusantara.com/wp-content/uploads/2017/12/bedahbukudisruption170430165621.pdf.

Alin Stăncioiu. “The Fourth Industrial Revolution „Industry 4.0”.Pdf.” Accessed May 9, 2018. http://www.utgjiu.ro/rev_mec/mecanica/pdf/201701/11_Alin\%20ST\%C4\%82NCIOIU\%20-

$\%$ 20the\%20fourth\%20industrial\%20revolution \%20\%E2\%80\%9eindustry\%20 4.0\%E2\%80\%9d.pdf.

"Al-Quran Online Bahasa Indonesia | Tafsirq.Com." Accessed May 1l, 2018. https://tafsirq.com/.

Arampatzi, Efstratia, Martijn J. Burger, and Natallia Novik. "Social Network Sites, Individual Social Capital and Happiness.” Journal of Happiness Studies, October 20, 2016, 1-24. https://doi.org/10.1007/s10902-016-9808-z.

aspirasi. "Prof Clayton M. Christensen : Disruptive Innovation," September 6, 2017. http://kumpulanstudi-aspirasi.com/ekonomi/prof-clayton-m-christensendisruptive-innovation/.

Brown, Sky, Britt Carter, Michael Collins, Christopher Gallerson, Grady Giffin, Jon Greer, Ray Griffith, Emily Johnson, and Kate Richardson. "Generation Y in the Workplace," n.d., 79.

Budi Agus Riswandi. "2017-07-27-Fh-Uii-Semnas-Inovasi-Teknologi-Dan-HakKekayaan-Intelektual-Fenomena-Disruptive-Innovation-Budi-Agus-RiswandiWord.Pdf." Accessed May 9, 2018. https:/law.uii.ac.id/wpcontent/uploads/2017/07/2017-07-27-fh-uii-semnas-inovasi-teknologi-dan-hakkekayaan-intelektual-fenomena-disruptive-innovation-budi-agus-riswandiword.pdf.

Chaer, Moh Toriqul. "The Deconstruction Of Character Education." International Journal of Technology And Business 1, no. 2 (2017): 56-62.

Debashish Sengupta. "Pmwj45-Apr2016-Sengupta-Investigating-Happiness-ofGenerationy-Millennials-Featured-Paper.Pdf.” Accessed May 9, 2018. https://pmworldjournal.net/wp-content/uploads/2016/04/pmwj45-Apr2016-

Sengupta-investigating-happiness-of-generationy-millennials-featuredpaper.pdf.

Fukuyama, Francis. (2005) The Great Disruption: Human Nature and the Reconstitution of Social Order. Translation: Masri Maris. Jakarta: PT Gramedia Pustaka Utama

Ghazali, Abu Hamid al-. Kimiya Al-Sa'adah. Kairo: Mathba'at al-Sa'adat, 1934. http://www.penerbitzaman.com/download/Kimia-Ruhani-untuk-

Kebahagiaan-Abadi.pdf.

Haque, A. (2004). Religion and mental health: The case of American Muslims. Journal of Religion and Health, 43(1), 45-58 
"Jalan-jalan Sekalian Shoping ke Mal." Tribun Pekanbaru. Accessed May 11, 2018. http://pekanbaru.tribunnews.com/2017/01/30/jalan-jalan-sekalian-shoping-kemal.

JawaPos.com. "Millennials Dan Disruption." Accessed May 9, 2018. https://www.jawapos.com/read/2017/05/16/130348/millennials-dan-disruption.

Joshanloo, M. (2013). A comparison of Western and Islamic conceptions of happiness. Journal of Happiness Studies, 14(6), 1857-1874. https://doi.org/10.1007/s10902012-9406-7

Kompasiana.com. “Mall, Jadi Gaya Hidup?” KOMPASIANA. Accessed May 11, 2018. https://www.kompasiana.com/richardo/mall-jadi-gayahidup_55010149a3331135195107b5.

Liao, Yongxin, Eduardo Rocha Loures, Fernando Deschamps, Guilherme Brezinski, André Venâncio, Yongxin Liao, Eduardo Rocha Loures, Fernando Deschamps, Guilherme Brezinski, and André Venâncio. "The Impact of the Fourth Industrial Revolution: A Cross-Country/Region Comparison." Production 28 (2018). https://doi.org/10.1590/0103-6513.20180061.

Mačkayová, Veronika Kuchárová, And Veronika Baláţ ová. "Characteristics Of Generation Y And Its Future Occupation - Comparison Of Opinions." Human Resources Management 1 (n.d.): 16.

Manago, Adriana M., and Lanen Vaughn. "Social Media, Friendship, and Happiness in the Millennial Generation." In Friendship and Happiness, edited by Melikşah Demir, 187-206. Dordrecht: Springer Netherlands, 2015. https://doi.org/10.1007/978-94-017-9603-3_1l.

Mujib, A., \& Mudzakir, J. (2001). Nuasa-nuasa psikologi Islam. Raja Grafindo Persada. Mujib, H. A. (2006). Kepribadian dalam psikologi Islam. PT Rajagrafindo Persada.Mujib, A., \& Daradjat, Z. (1999). Fitrah dan kepribadian Islam: sebuah pendekatan psikologis. Darul Falah.

Nicholas, Arlene J. "Preferred Learning Methods of the Millennial Generation." The International Journal of Learning: Annual Review 15, no. 6 (2008): 27-34. https://doi.org/10.18848/1447-9494/CGP/vl5i06/45805.

"Pengembangan Iptek dan Pendidikan Tinggi di Era Revolusi Industri 4.0." ristekdikti (blog). Accessed May 10, 2018. https://www.ristekdikti.go.id/pengembanganiptek-dan-pendidikan-tinggi-di-era-revolusi-industri-4-0/.

"Peringkat Kebahagiaan Indonesia Di Tengah." Accessed May 11, 2018. https://beritagar.id/artikel/infografik/peringkat-kebahagiaan-indonesia-ditengah.

"Positive Psychology Initiatives | Authentic Happiness." Accessed May 10, 2018. https://www.authentichappiness.sas.upenn.edu/learn.

Putra, Yanuar Surya. "Teori Perbedaan Generasi," 2016, 12.

Seligman, Martin E. P. "Martin Seligman_Learned Optimism.Pdf," n.d.

_-_ . "Seligman-PosPsychProgress.Pdf," n.d.

Seligman, Martin E. P., Tracy A. Steen, Nansook Park, and Christopher Peterson. "Positive Psychology Progress: Empirical Validation of Interventions." American Psychologist 60, no. 5 (2005): 410-21. https://doi.org/10.1037/0003-066X.60.5.410. 
Seligman, M. E., Steen, T. A., Park, N., \& Peterson, C. (2005). Positive psychology progress: empirical validation of interventions. American psychologist, 60(5), 410.

Shiota, M. N., Campos, B., Oveis, C., Hertenstein, M. J., Simon-Thomas, E., \& Keltner, D. (2017). Beyond happiness: Building a science of discrete positive emotions. American Psychologist, 72(7), 617.

Seligman, M. E., \& Csikszentmihalyi, M. (2014). Positive psychology: An introduction. In Flow and the foundations of positive psychology (pp. 279-298). Springer Netherlands.

Sahraian, A., Gholami, A., Javadpour, A., \& Omidvar, B. (2013). Association between religiosity and happiness among a group of Muslim undergraduate students. Journal of Religion and Health, 52(2), 450-453. https://doi.org/10.1007/sl0943. 011-9484-6

Setiawan, Wahyudi. “Al-Qur'an Tentang Lupa, Tidur, Mimpi Dan Kematian” 2 (2016): 20.

———. "Fanatisme Dalam Berorganisasi," n.d., 25.

___ _. "Reward and Punishment dalam Perspektif Pendidikan Islam," n.d., 18.

Stanimir, Agnieszka. "Generation Y - Characteristics of Attitudes on Labour Market." Mediterranean Journal of Social Sciences, April 1, 2015. https://doi.org/10.5901/mjss.2015.v6n2s5p22.

VSB - Technical University of Ostrava, and Petra Klapilova Krbova. "Generation Y Attitudes towards Shopping: A Comparison of the Czech Republic and Slovakia." Journal of Competitiveness 8, no. 1 (March 31, 2016): 38-54. https://doi.org/10.7441/joc.2016.01.03.

"What Is Well-Being? | Authentic Happiness." Accessed May 10, 2018. https://www.authentichappiness.sas.upenn.edu/learn/wellbeing.

Yongxin Liao et al., "The Impact of the Fourth Industrial Revolution: A CrossCountry/Region Comparison," Production $28 \quad$ (2018), https://doi.org/10.1590/0103-6513.20180061. 